\title{
Prevalence of cholelithiasis in patients with chagasic megaesophagus
}

\section{Prevalência de colelitíase em pacientes com megaesôfago chagásico}

\author{
Eduardo Crema ${ }^{1}$, Ellen Caroline Rosa Resende Silva ${ }^{2}$, Priscila Melo Franciscon ${ }^{2}$, Virmondes Rodrigues Júnior ${ }^{3}$, \\ Aiodair Martins Júnior ${ }^{1}$, Celso Júnior Oliveira Teles ${ }^{2}$ and Alex Augusto Silva ${ }^{1}$
}

\begin{abstract}
Introduction: The prevalence of cholelithiasis in the general population ranges from 9 to $18 \%$. This prevalence is known to be higher in the presence of parasympathetic nerve damage of the biliary tract either due to surgery (vagotomy) or neuronal destruction (Chagas disease). The objective of this study was to evaluate the association of cholelithiasis and chagasic or idiopathic megaesophagus. Methods: The ultrasound scans of 152 patients with megaesophagus submitted to cardiomyotomy and subtotal esophagectomy surgery were evaluated. The presence of cholelithiasis was compared between chagasic and idiopathic esophagopathy and ultrasound and clinical findings were correlated with age, sex and race. Results: A total of 152 cases of megaesophagus, including 137 with chagasic megaesophagus and 15 with idiopathic megaesophagus, were analyzed. The mean age was 56.7 years (45-67) in the 137 patients with chagasic megaesophagus and 35.6 years (27-44) in the 15 cases of idiopathic megaesophagus, with a significant difference between the two groups $(\mathrm{p}<0.0001)$. The group with chagasic megaesophagus consisted of $59(43 \%)$ women and $78(56.9 \%)$ men, while the group with idiopathic megaesophagus consisted of 8 (53.3\%) women and 7 (46.6\%) men, showing no significant difference between the groups. Of the 137 patients with confirmed chagasic megaesophagus, 39 (28.4\%) presented cholelithiasis versus one case (6.6\%) in the 15 patients with idiopathic megaesophagus. Conclusions: The prevalence of cholelithiasis is high in patients with chagasic megaesophagus and preoperative ultrasound should be performed routinely in these patients in order to treat both conditions during the same surgical procedure. Keywords: Chagas disease. Cholelithiasis. Megaesophagus. Gallbladder denervation.
\end{abstract}

\section{RESUMO}

Introdução: A prevalência de colelitíase observada na população em geral varia de 9 a $18 \%$. Sabe-se que a prevalência de colelitíase é elevada quando existe lesão nervosa parassimpática das vias biliares, causada tanto por procedimentos cirúrgicos (vagotomias), quanto por destruição neuronal, como observado na forma digestiva da doença de Chagas. Propusemo-nos verificar a associação entre megaesôfago de etiologia chagásica e a presença de colelitíase. Métodos: Avaliou-se prospectivamente o exame ultrassonográfico de 152 pacientes portadores de megaesôfago submetidos à cirurgia de cardiomiotomia e esofagectomia subtotal. Analisouse comparativamente a esofagopatia chagásica e a idiopática com a presença de colelitíase, correlacionando os dados ultrassonográficos com os achados clínicos, idade, sexo e raça. Resultados: Foram analisados 152 casos de megaesôfago, sendo 137 de etiologia chagásica e 15 idiopáticos. Entre os chagásicos, a idade média foi de 56,7 anos (45-67); e nos idiopáticos, a média de idade foi de 35,6 anos (27-44), verificando-se diferença significativa $(p<0,0001)$ em relação à média de idade. Dos 137 chagásicos, 78 (56,9\%) eram do sexo masculino; entre os 15 idiopáticos, 7 (46,6\%) eram do sexo masculino. A comparação entre os grupos em relação ao gênero não mostrou diferença significativa. Dentre os 137 chagásicos detectou-se $39(28,4 \%)$ casos de colelitíase e, dentre os 15 casos de megaesôfago idiopático, constatou-se colelitíase em apenas um (6,6\%). Conclusões: Conclui-se que portadores de megaesôfago chagásico possuem alta prevalência de colelitíase, e que a ultrassonografia deve ser realizada rotineiramente no pré-operatório, a fim de tratar ambas as afecções no mesmo ato cirúrgico. Palavras-chaves: Doença de Chagas. Colelitíase. Megaesôfago. Desnervação da vesícula biliar.

1. Disciplina de Cirurgia do Aparelho Digestivo, Universidade Federal do Triângulo Mineiro, Uberaba, MG. 2. Curso de Medicina, Universidade Federal do Triângulo Mineiro, Uberaba, MG. 3. Disciplina de Imunologia, Universidade Federal do Triângulo Mineiro, Uberaba, MG.

Address to: Dr. Eduardo Crema. Rua Marcos Lombardi 305, Santos Dumont, 38050-170 Uberaba, MG, Brasil.

Phone: 5534 7811-3830; 5534 3318-5228

e-mail: cremauftm@mednet.com.br

Received in 15/06/2010

Accepted in 08/02/2011

\section{INTRODUCTION}

The chronic digestive form of Chagas disease is characterized by the destruction of intramural ganglia and parasympathetic denervation throughout the digestive tract, especially affecting the esophagus ${ }^{1}$ and rectosigmoid junction. However, studies investigating accessory organs and glands of the digestive tract in Chagas disease, particularly the gallbladder, are scarce ${ }^{2-4}$. The incidence of cholelithiasis is high in the presence of parasympathetic nerve damage of the biliary tract either due to surgery (vagotomy) ${ }^{5,6}$ or neuronal destruction ${ }^{1}$. Similarly, the incidence of cholelithiasis is higher in chagasic patients than in the general population ${ }^{2,4}$. The following factors have been highlighted as responsible for this increase: gallbladder denervation leading to alterations in organ tonus and contractility and consequently diminished biliary flow and greater stasis $^{2,4}$; hypostimulation of the gallbladder by cholecystokinin due to lower supply of foods to the stomach and duodenum as a result of poor swallowing in cases of megaesophagus and of anorexia in cases of megacolon; alterations in gastroduodenal function, such as vagal denervation of the stomach that diminishes intestinal motility and gastric juice acidity; elevated secretion of saliva and mucus in cases of megaesophagus that neutralize the gastric juice, reducing stimuli for cholecystokinin secretion $^{2}$, have also been reported to contribute to the formation of cholelithiasis. Furthermore, in the case of patients with megaesophagus and megacolon, denervation of the small bowel probably reduces the absorption of bile salts and consequently triggers the formation of lithogenic bile ${ }^{2,4}$.

Given the scarcity of literature data, the aim of the present study was to evaluate the association between megaesophagus and cholelithiasis in chagasic patients attended at the University Hospital of the Universidade Federal do Triângulo Mineiro (UFTM). 


\section{METHODS}

Ultrasound scans of the gallbladder of 152 patients with megaesophagus treated at the Digestive Surgery Service of UFTM were analyzed. All patients were submitted to Heller cardiomyotomy or subtotal esophagectomy. The scans were analyzed regarding the presence of cholelithiasis, bile duct dilatation and/ or choledocholithiasis. Chagasic megaesophagus was considered when the patient presented a positive result in at least two of the three following tests: ELISA, passive hemagglutination and indirect immunofluorescence, or positive polymerase chain reaction (PCR) in a myotomy fragment or surgical specimen, associated with histopathological alterations characteristic of chagasic megaesophagus. Patients not presenting these conditions were classified as presenting idiopathic megaesophagus. The presence of cholelithiasis was compared between chagasic and idiopathic esophagopathy. The ultrasound and clinical findings were correlated with age, sex and race.

The results were analyzed statistically by the $\mathrm{x}^{2}$ test, with the level of error probability set at $5 \%$. Parametric analysis of variance (ANOVA, F test) was used to determine possible differences in age, gender and race between the chagasic and idiopathic groups.

\section{RESULTS}

A total of 152 patients with megaesophagus submitted to surgical treatment at the Digestive Surgery Service of UFTM were studied. Of these, 137 presented chagasic megaesophagus and 15, idiopathic megaesophagus.

The mean age of patients with chagasic megaesophagus was 56.7 (45-67) years-old and the mean age of patients with idiopathic megaesophagus was 35.6 (27-44) years-old, showing a significant difference between the groups. Seventy-eight (56.9\%) of the 137 patients with chagasic megaesophagus were males and $59(43.1 \%)$ were females. In the idiopathic group, 8 (53.3\%) were men and 7 (46.7\%) were women. Despite the predominance of male patients in the chagasic group, no significant difference was observed (Figures 1, 2 and 3).

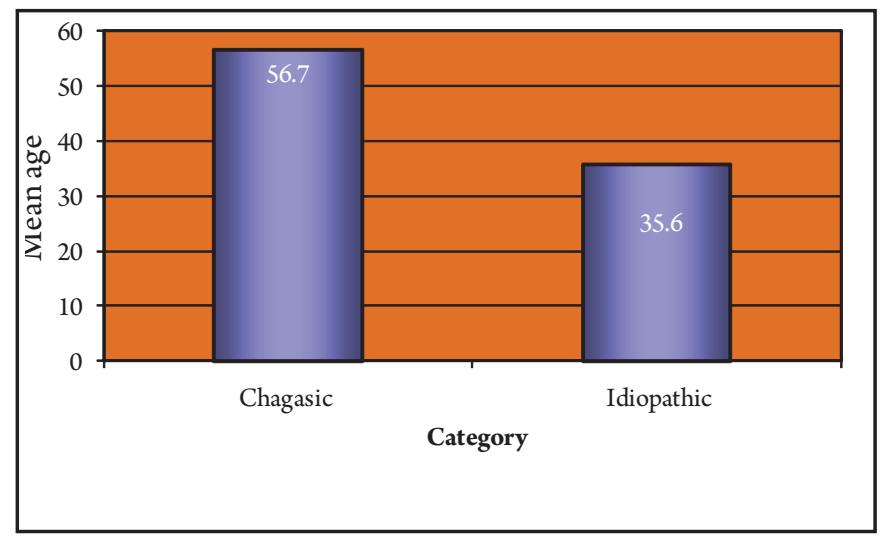

FIGURE 1 - Distribution of patients with chagasic (CH) and idiopathic (ID) megaesophagus according to age $(n=152)$.

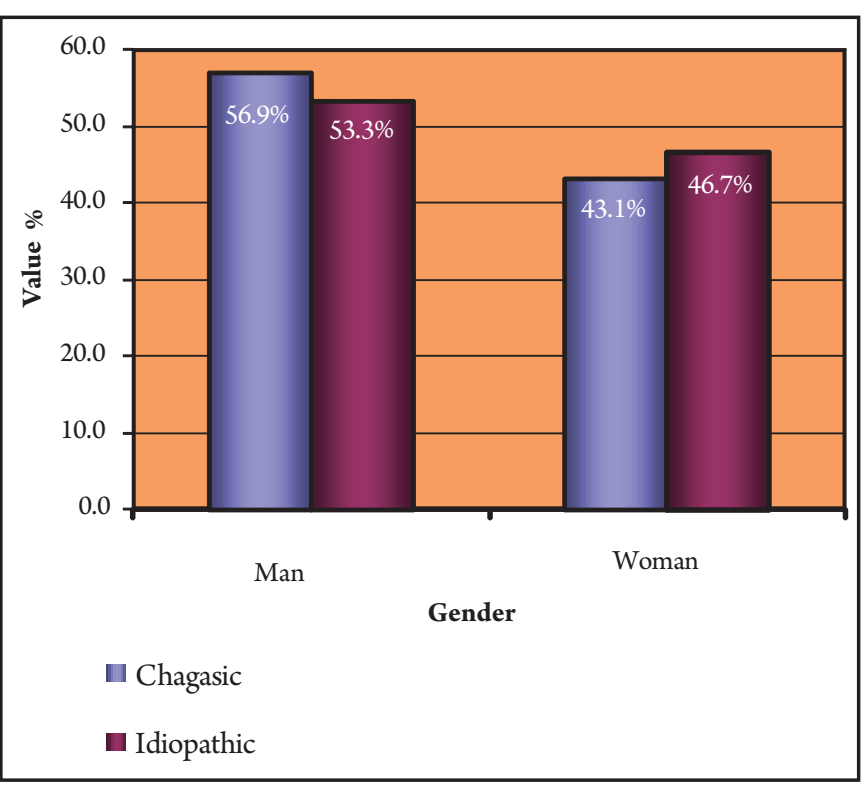

FIGURE 2 - Distribution of patients with chagasic (CH) and idiopathic (ID) megaesophagus according to gender $(n=152)$.

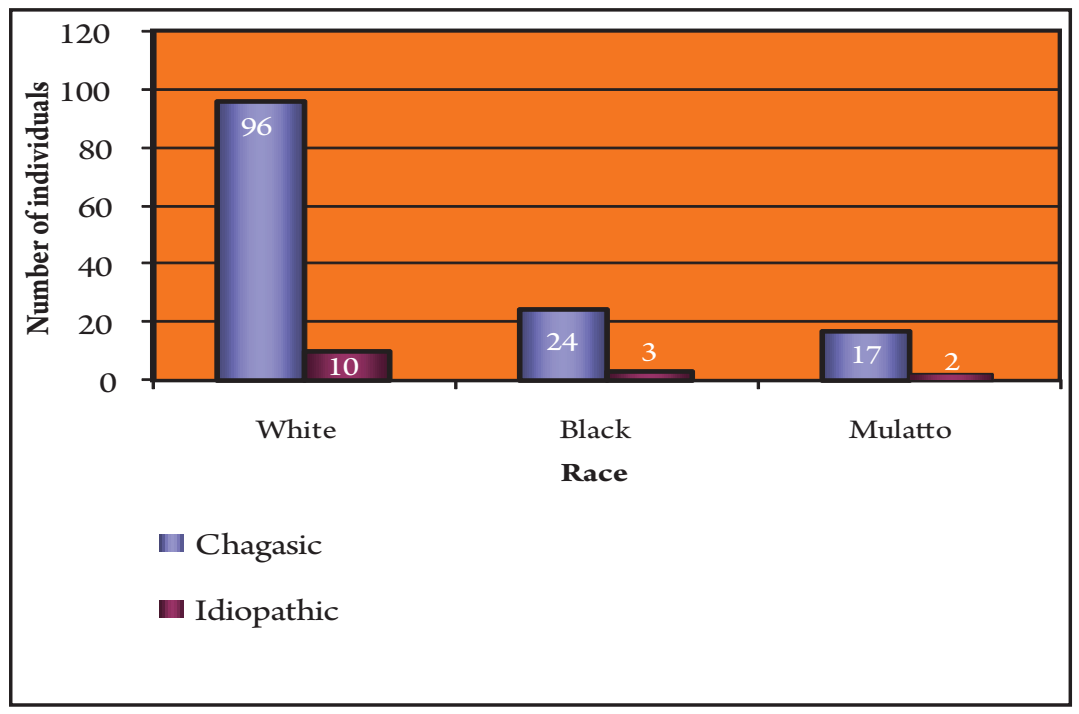

FIGURE 3 - Distribution of patients with chagasic (CH) and idiopathic (ID) megaesophagus according to race $(n=152)$. 
A predominance of white patients was observed in both groups, with $96(70 \%)$ cases in the chagasic group and $10(66.7 \%)$ in the idiopathic group, followed by blacks [24 (17.5\%) chagasic and 3 (20\%) idiopathic] and mulattos [17 (12.4\%) chagasic and 2 (13.3\%) idiopathic].

Cholelithiasis was present in 39 (28.4\%) of the 137 patients with chagasic megaesophagus and in $1(6.7 \%)$ of the 15 patients with idiopathic megaesophagus (Figures $4 \mathbf{A}$ and $\mathbf{B}$ ). This difference was statistically significant. Despite the high incidence of cholelithiasis in patients with chagasic megaesophagus, the rates of choledocholithiasis observed in this series were not higher than those reported for the general population (9.2 to $18 \%$ ).

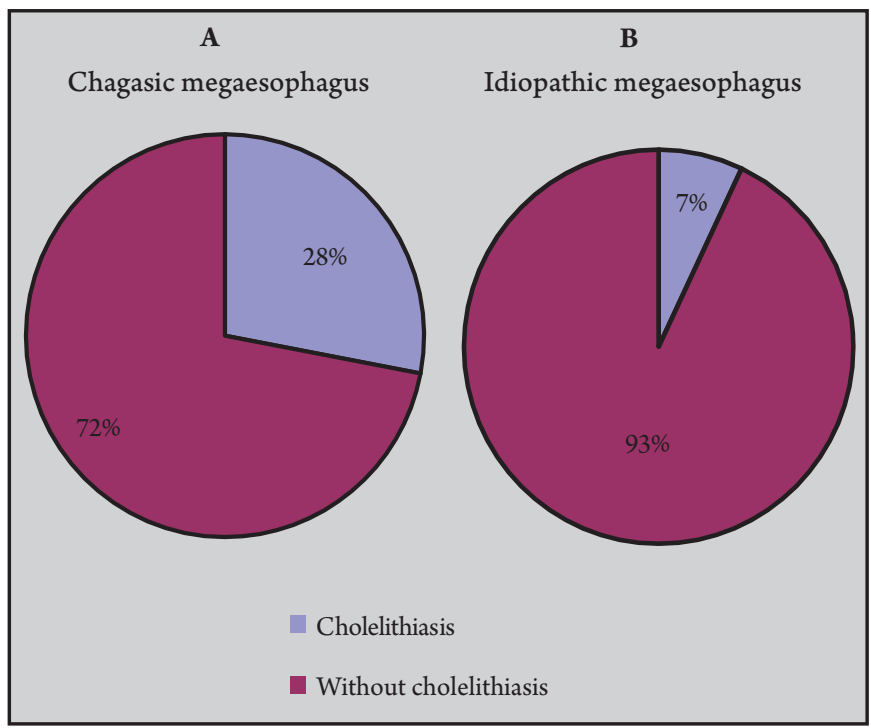

FIGURE 4 - A: Prevalence of cholelithiasis in patients with chagasic megaesophagus $(n=137)$, and $(B)$ : in patients with idiopathic megaesophagus $(\mathbf{n}=\mathbf{1 5})$.

\section{DISCUSSION}

Studies investigating the gallbladder in Chagas disease are scarce ${ }^{7}$. Therefore, the objective of the present study was to evaluate the incidence of cholelithiasis in patients with megaesophagus. According to the literature, the incidence of cholelithiasis is high in the presence of parasympathetic nerve damage of the biliary tract either due to surgery (vagotomy) ) $^{5,6,8}$ or to neuronal destruction, as observed in the chronic digestive form of Chagas disease ${ }^{1,2,9}$. One study reported a prevalence of cholelithiasis of $8.4 \%$ in patients with chagasic megaesophagus, but observed no case of cholelithiasis among patients with idiopathic megaesophagus. In the present study, the rate of cholelithiasis in patients with megaesophagus (28.4\%) was much higher than that reported previously, probably because of the routine use of preoperative ultrasound in these patients.

No significant difference in sex or race was observed between patients with idiopathic and chagasic megaesophagus. However, a significant difference in age was observed between the two groups; patients with idiopathic megaesophagus were younger than those with chagasic megaesophagus.

In conclusion, the prevalence of cholelithiasis is high in patients with chagasic megaesophagus and it is good practice to perform a preoperative ultrasound routinely in these patients in order to treat both conditions during the same surgical procedure.

\section{CONFLICT OF INTEREST}

The authors declare that there is no conflict of interest.

\section{REFERENCES}

1. Adad SJ, Resende AV, Jorge BH. Estudo sistematizado do plexo mientérico nos diferentes terços do esôfago de chagásicos crônicos com e sem megaesôfago. Rev Soc Bras Med Trop 1992; 25:101.

2. Pinotti HW, Raia A, Bettarello A, Conte VP. Ocorrência de colelitíase em portadores de megaesôfago chagásico. Estudo comparativo com não chagásicos. Rev Hosp Clin Fac Med S Paulo 1980; 35:21-24.

3. Pinotti HW, Felix VN, Zilberstein B, Cecconello I. Surgical complications of Chagas' disease: megaesophagus, achalasia of the pylorus and cholelithiasis. World J Surg 1991; 15:198-204.

4. Oliveira LCM, Nascimento RS, Rocha A, Gonçalves EAG, Silva JMF, Oliveira VA, et al. Colelitíase em chagásicos crônicos. Arq Gastroenterol 1997; 34:222-226.

5. Diaconescu MR, Simon I, Costea I, Glod M, Terinte R. Cholelithiasis following gastric surgery. Chirurgia 1997; 92:343-347.

6. Kinoshita H, Imayama H, Hashino K, Aoyagi S. Study of cholelithiasis after gastrectomy. Kurume Med J 2000; 47:105-108.

7. Rocha A, Almeida H, Teixeira VPA, Silva AM. Prevalência da colelitíase em chagásicos crônicos necropsiados no Triângulo Mineiro - correlação com o megaesôfago, o megacólon e a insuficiência cardíaca. Arq Gastroenterl S Paulo $1985 ; 22: 3-6$.

8. Iorio A, Chattas E, Kesner L, Masciangioli G, Zampini E, Gandval C. Litiasis vesicular post-vagotomia y operaciones gastricas. Prensa Med Argent 1983; 70:113-116.

9. Crema E, Ribeiro LBP, Adad SJ, Ectchebere RM, Martins Jr A, Silva AA Contagem de neurônios da vesícula biliar de pacientes chagásicos e não chagásicos portadores de colelitíase. Rev Soc Bras Med Trop 2007; 40:15-17. 